\title{
ENRICHING THE HISTORY SURVEY COURSE WITH "MINI-DOCUMENTARIES"
}

\author{
Kevin S. Krahenbuhl \\ Middle Tennessee State University
}

\section{Introduction}

From 2007 through 2012 I had the great privilege of teaching history survey courses at several institutions of higher education. The survey course typically includes a body of factual knowledge to be learned as well as a set of themes/concepts to be analyzed in further detail. ${ }^{1}$ There has been much discussion over the past several decades for how to properly reform the survey courses. ${ }^{2}$ Even with all this discourse, the history survey course is still ubiquitous in its basic design throughout higher education. Given its resiliency, the survey course is not likely to disappear. The question rather, will be through what format and content foci the history survey course will continue to be implemented. This article describes my inclusion of student-created mini-documentaries in the history survey course as a supplement to seeing the themes that weave throughout history, practice skills of historical inquiry, and increase engagement without throwing out the delivery of content.

\section{Background}

I am not one of the many voices who despise the lecture; I actually believebased on rudimentary, yet observed evidence - that it is still one of the most effective elements of pedagogy at our disposal. ${ }^{3}$ However, I have never been one who designed a course in which I was nothing more than a "sage on the stage" simply imparting wisdom to ignorant students. Rather, I consistently incorporate various teaching approaches into the course to enliven the experience and get students to engage with

\footnotetext{
${ }^{1}$ Joel M. Sipress \& David J. Voelker, "The End of the History Survey Course: The Rise and Fall of the Coverage Model," The Journal of American History 97 (March 201 1), 1050-1066.

${ }^{2}$ Lendol Calder, "Uncoverage: Toward a Signature Pedagogy for the History Survey," The Journal of American History 93 (March 2006), 1358-1370. Calder is often credited with bringing this discussion to the main stage through his uncoverage approach in which he argues the "facts first" approach of survey courses is "wrongheaded."
}

${ }^{3}$ For three semesters I ran a series of unpublished pre/post-test experiments evaluating student learning growth based on use of different teaching methodologies for different units and have found so far that, when didactic lecture is the primary method, the learning growth (in terms of growth from pre to posttest) is highest. This is, of course, not definitive but illustrative that my position is grounded in empirical evidence and in comparison with the flipped model and William Perry's argument-based historical study approach. 
history rather than just be exposed to it. Such approaches include examining the evidence through document analysis, considering conflicting accounts of historical events and seeking to confirm what is corroborated and likely to be the facts of the case, engaging in sub-group discussions looking at the same topic through social, cultural, economic, and political lenses, among other approaches. Each of these provides good opportunities to take structured "breaks" where we can have the students process the information that is being presented and apply historical thinking to it in a fashion similar to that described by Robert Blackey in Teaching History. ${ }^{4}$

Upon being hired for my first collegiate teaching position, I was assigned several survey courses. I went through the process of designing my syllabus and built into the course a project that has benefitted the class, the students, and my own practice of history. That project is what I refer to as the student creation of a "mini-documentary." This assignment effectively took the place of the traditional term paper as students were required to choose a topic of significance for the course being studied, connect it to one of the course-driving themes, and throughout the semester engage in historical inquiry by asking questions, researching, locating primary documents and other sources of information, and creating a video presentation that tells the story of that event, person, or idea. ${ }^{5}$

\section{Course Design Thematically}

I have implemented the project of student-created mini-documentaries through several different approaches: student-selected topics of interest, a master list of various topics, and thematic instructor-selected topics. Based on personal and professional reflections as well as written comments from student opinion surveys, I have come to the conclusion that the best approach is the utilization of thematic, instructor-selected topics. ${ }^{6}$ In doing so, I have found that the projects seamlessly connect to key aspects of our study throughout the semester and that their presentations enrich the overall experience as they revisit concepts and information we have discussed but from a new perspective. Students also echo this sentiment with many positive comments, such as

${ }^{4}$ Robert Blackey, "“We'll be right back': Introducing Constructive 'Breaks' into History Lectures," Teaching History 37, 2 (2012), 59-68.

${ }^{5}$ I have noticed a significant increase in the entry abilities of students for using various software packages to create these videos. However, one could easily integrate a short session on "how-to" use one or several such products. Later I'll address how I simply refer them to Lynda.com.

${ }^{6}$ As one might expect, when left undirected, the students often picked such mundane or arbitrary topics that they did not provide a constructive means to integrate them into the course. Thus, I follow a more content-and-context-driven model for selecting the topics; I would likely revisit the student-choice aspect were I teaching a graduate course. 
one from a student in the spring of 2012 who stated, "The documentaries helped me learn more about how patterns of interaction are [sic] in history." Thus, the presentations aid the overall class by building in review of material, which is essential to the mastery of content knowledge, and allowing students to conclude the course with a clear picture of how the themes from which the presentation are derived weave throughout the narrative of history.

\section{Implementing Mini-Documentaries in the Course}

If you are interested in introducing mini-documentaries into your course, first consider some of the following questions before assigning the project. Do you want to require students to focus on the big picture or can they take a specific lens to look through? Are they welcome to present the story through a single specific perspective or must they consider several? What will your evaluation be based on? To what degree must students connect their topic to the theme under which it is placed? These are just a few questions to get you thinking (please refer to the appendices to see a sample of my assignment). Once you've determined how you wish to implement the minidocumentary so it fits your own preferences for historical inquiry, then I encourage you to build in the steps that follow in this model.

Early in the semester I typically have students complete a pre-course quiz, which consists of twenty questions drawn from a U.S. citizenship examination. This serves two purposes: (1) I can demonstrate that my students, overwhelmingly U.S. citizens, really lack a strong foundation in civic/historical knowledge, and (2) I can get them to start thinking critically about the great number of people who choose to migrate to the United States and that we require them to learn this material while many native born citizens remain ignorant about their own national history. This provides a context for an early engaging activity. I can generate discussion on the importance of civil aptitude and transition into a key goal for the course: developing a critical understanding of the key aspects that make us who we are. I also use the scores to have students sign up for topics so those who score the highest are rewarded with first selections and so on. ${ }^{7}$

During the next class session, I introduce the mini-documentary project. Students will select their topic and get a brief orientation over what is required for the project. ${ }^{8}$ Over the course of the semester, I require several distinct steps to move them through the process, but this is overwhelmingly an out-of-class project just as writing a term

\footnotetext{
${ }^{7}$ Alternatively, I have also gone inverse-order, justifying it on the grounds that those with more prior knowledge are more likely to handle some of the less popular topics with more skill—something to consider.
}

${ }^{8} \mathrm{I}$ have provided a copy of the assignment page in Appendix A for readers' reference. 
paper would be. Table 1 illustrates the steps I include in the course to guide students through the creation and presentation of their mini-documentaries.

Table 1: Semester Planning for the Mini-Documentary Project

\begin{tabular}{|l|l|l|}
\hline Step/Week & \multicolumn{1}{|c|}{ Activity } & Details \& Historical Thinking Skills \\
\hline 1-Week 1 & Citizenship Exam & $\begin{array}{l}\text { Context for class \& determining order for topic } \\
\text { selection }\end{array}$ \\
\hline 2-Week 2 & $\begin{array}{l}\text { Topic Selection \& } \\
\text { Thematic Introduction }\end{array}$ & $\begin{array}{l}\text { Students select topic and begin rudimentary } \\
\text { online research to get a basic foundation before } \\
\text { going to the library to do research } \\
\text { Teacher explains the themes connecting the } \\
\text { topics and how they are integrated into the } \\
\text { course design }\end{array}$ \\
\hline $3-$ Week 3 & Library Orientation & $\begin{array}{l}\text { Librarian provides a class-focused orientation } \\
\text { on research, academic versus public resources, } \\
\text { and general historical research skills } \\
\text { Students must find three scholarly sources in } \\
\text { addition to one primary source before leaving }\end{array}$ \\
\hline $4-$ Week 8 & Project Outline & $\begin{array}{l}\text { Students present a basic outline for how they } \\
\text { intend to tell the story of their topic so as to } \\
\text { assess their historical comprehension of the } \\
\text { topic }\end{array}$ \\
\hline $5-$ Week 9 & $\begin{array}{l}\text { Annotated Bibliography } \\
\text { Draft }\end{array}$ & $\begin{array}{l}\text { Students must submit a draft version of their } \\
\text { annotated bibliography including at least eight } \\
\text { sources, including at least two primary sources }\end{array}$ \\
\hline 6-Week 12 & $\begin{array}{l}\text { Confirmation of their } \\
\text { readiness to present and }\end{array}$ & $\begin{array}{l}\text { Students are required to contact professor } \\
\text { indicating that either (a) they have no } \\
\text { questions and will be ready to present or (b) } \\
\text { ask questions they have and then address (a) } \\
\text { and submit their planned narrative for review } \\
\text { regarding historical analysis and interpretation }\end{array}$ \\
\hline Documentaries & $\begin{array}{l}\text { Students bring in two electronic copies of their } \\
\text { presentations; one submitted to professor for } \\
\text { follow-up review, one for themselves and just- } \\
\text { in-case of technical issues }\end{array}$ \\
\hline
\end{tabular}

The project effectively integrates the elements of historical inquiry, including comprehension, historical analysis, and interpretation, as it exercises their historical 
research capabilities and compels them to work with historical issues analysis. ${ }^{9}$ Following the contextual foundation that the citizenship exam provides, I explain the project in detail and attempt to give it relevance by reminding them that they have an opportunity to do history while utilizing twenty-first century skills. The library orientation concludes our introductory stage to the project and, from this point, students complete their assignment entirely out of class. However, I also purposefully integrate activities in weeks three through eight that place clarity and emphasis on how historians work. For example, early on, students complete an in-class document analysis of primary sources, do comparative perspective activities, and "do history" in-and-out of class. During debriefing of those activities, I deliberately connect these essential elements of doing history with the ongoing mini-documentary assignment.

Once students complete these activities to practice doing history properly, they then submit a project outline and prepare an annotated bibliography. These activities assess their capacity to contextualize and apply their historical research skills. Multiple comments in our annual evaluations suggest student appreciation for the design of this project in stages. One remark from 2012 reflects that common pattern: “... although we had to do a lot of work in the class, I saw how it all went together and even though I don't want to be a history teacher I think that seeing how the skills applied in class and on our documentary was great for me as a college of education student."

The final confirmation of readiness that students share involves a compulsory meeting where they acknowledge they are ready or they address any questions that remain. In this meeting, the students briefly share their script, explain their source selections and interpretations, and ask questions that may exist. As such it offers an opportunity for specific feedback and a quick pre-screening of the material that will be presented. This process is something I added in, but I have found this step immensely useful-after implementing this step, I have almost no instances of students who contact me at the last minute with "the flu," "a car accident," or any other excuse for not getting their project done. Finally, student presentations of the mini-documentaries display their capacity to utilize historical analysis and interpretation effectively. ${ }^{10}$ The opportunity to share their work with others serves a three-fold purpose: (1) it adds

\footnotetext{
${ }^{9}$ These tasks fit nicely within the frames offered by the National Center for History in the Schools, "National Standards for History Basic Edition." See National Center for History in the Schools, National Standards for History, Basic Edition (Los Angeles: Nation Center for History in the Schools, 1996). These can be accessed online at http://www.nchs.ucla.edu/history-standards.
}

\footnotetext{
${ }^{10}$ It is worth noting that while reading through all the scripts does take time, it is a powerful opportunity for the professor to ensure that what is presented to the class is worthy of sharing. It can also be a great learning experience for the future history majors as they can sit down with the professor one-on-one to review their historical comprehension of the context, their analysis and interpretation, their research capabilities, and their effectiveness of taking on the significance of the relevant historical issues in a pseudo-defense.
} 
pressure to create a worthy product because it won't just be me judging it; (2) it offers up opportunities for in-class discourse on issues of historical inquiry; and (3) it serves well for a review of the major themes and topics of the course-assuming you pre-pick them purposefully in line with what your final examination will assess.

Another benefit of living in a digital age is that the mini-documentaries can easily be uploaded to YouTube or other forums where students can view them per your requirement if you do not have enough time to view all of them during class. In the survey courses I have taught, my enrollments have been capped at a number reasonable to allow me to show the documentaries to class and in class. I find it useful to discuss issues that arise at the time of the presentations and connect them clearly to the theme under which they are placed.

Even if you are not a professor who is tech-savvy, getting students to create these mini-documentaries does not necessarily require any in-class time to prepare them. Lynda.com has wonderful and free resources available via the World Wide Web to give students easy-to-follow crash courses for how to use programs such as Windows Movie Maker, iMovie, etc. In some semesters I spend part of one class session showing students how to use these tools (typically in spring when I had fewer days missed due to holidays). However, in most semesters I just build a homework assignment into my syllabus requiring students to view one of these videos. Virtually all students were able to create a video without many questions. ${ }^{11}$

\section{Discussion}

This approach requires students to engage in critical historiography by telling the story of important people, events, and ideas of history. But creating a minidocumentary is not something that applies only to survey courses. I have instituted the same assignment, again driven by related themes of history and significant figures, events, and ideas, in specialized courses as well and had great success. ${ }^{12}$ The model I've created for the integration of these mini-documentaries does not require excessive class time, although that obviously is contingent upon the number of students in the survey course.

\footnotetext{
${ }^{11}$ To be expected perhaps, many non-traditional students were concerned about the assignment, as they would have preferred simply to write an essay (frequent comments from them). But some of the best presentations ultimately came from these non-traditional students. Requiring them to do the activity allowed them to step outside their comfort zone and produce something they were proud of.
}

${ }^{12}$ In a subsequent faculty position, I taught courses on American Indian Studies and Geography and integrated this project into both of them with great results. Also worthy of note, the students respond favorably to this activity as the creation of them fits the twenty-first century world in which we live and they can more easily see its "relevance," which is so frequently cited by Millennials. 
Let me close with a few lessons learned through several years of assigning students to create mini-documentaries. First, students need clarity and direction but not a template. Early on in my planning for this activity, I provided students with a sample video, until I found that the students would simply replicate my video, using the exact format and just altering the information to fit their chosen topic. So, it is essential that you provide clear requirements while leaving some latitude in structure.

Second, simply saying that they are creating mini-documentaries does not mean they have ever seen one with which they can connect. Many students today, even if they watch the History Channel, have not been exposed to traditional and powerful documentaries that focus on telling the truth of a story rather than presenting an agendadriven piece. ${ }^{13}$ In order to fill this gap in knowledge, I always build time into class to view a powerful documentary that shows the use of still-shots, background music, lighting, and narrative to tell a compelling story of human experience. ${ }^{14}$ Furthermore, the teaching of historical skills and deliberately connecting them to the project helps correct the tendency of students to draw mistaken grand conclusions or to make politicized statements without historical congruence, corroboration, and accuracy.

Third, compel students to review, confirm the accuracy of, and revise the draft of their narration prior to recording. Having used both peer review and professorreview, I have found that, while both help, the final products will be much better if I can take time to review them. Since most of my survey courses have had manageable numbers, I have settled on requiring students to submit the narrative (what they will say during the video) two weeks prior to the deadline. I review them, confirm they are accurate, evaluate whether they apply historical skills and interpretation appropriately, and provide basic guidance to improve them, so that they have sufficient time to revise before presenting. Should you teach a large section of the history survey, this would be a perfect assignment for your teacher's assistant, as the critical evaluation of another's "historical work" is arguably the best way to refine your own historical practice. Or, conversely, you could simply require the outline to be more detailed, which might achieve the same end.

Finally, I have tried on two separate occasions to integrate a secondary presentation prior to the final exam (see Appendix C). Although this add-on produced some excellent products, I ultimately decided not to continue to use it. This addition to the mini-documentary assignment used the final regular class period to have students engage with one another and connect the dots between their topics as they relate to an

\footnotetext{
${ }^{13}$ Regrettably, in my view, the History Channel has dropped the proverbial ball in this regard and abandoned the showing of documentaries in favor of entertaining.

${ }^{14}$ For American history survey courses I highly recommend PBS American Experience: The Donner Party video, which is powerful, engaging, and not overly tech-driven. This program provides a realistic sample in addition to great fodder for discussion with the harrowing and transcendent tale it tells.
} 
overarching theme. ${ }^{15}$ When I assigned this group activity, each set of students was required to create a PowerPoint that prepared students for a final exam question on that theme that related to all their topics. In doing so, they would receive the final exam essay question on their theme and have the entire class session to discuss with one another how their topics related to the theme and essay question and formulate an organized response. Too often, students simply could not put together useful connections, making it a questionable use of class time. ${ }^{16}$

\section{Conclusion}

As we continue to reflect on what we do, implement new ideas, and continue the process of teaching history in a way that is most effective, let us not be guided solely by theoretical constructs but rather by strategies confirmed through empirical evidence. Many critics discuss the low engagement of the lecture, but maybe the lecture is not the problem but rather how it is used-and, too, how frequently the lecture method is employed exclusively. In fact, one of the most common issues in pedagogical discourse among professionals deals with consistent decrying of the lecture as passive and ineffective and in its place favoring anything collaborative. I personally question the wisdom of that argument. Some history faculty have sought to throw out the lecture, but I think it is far more prudent that we instead look at what we can do to supplement the lecture and delve into the richness of historical inquiry to augment continued use of the lecture. ${ }^{17}$ This integration of a thematic-driven, expert-designed series of minidocumentaries offers an appropriate model for twenty-first century instruction and an opportunity for the enrichment so frequently sought.

We have all heard that those who do not learn from history are condemned to repeat it. Although this line is a cliché, I believe that there is a prudent allegory here.

\footnotetext{
${ }^{15}$ I have also included a list of sample essay questions, themes, and instructions for this approach in the appendices.

${ }^{16}$ One group in a U.S. History II survey course were all assigned influential leaders in America and put together one of the best presentations I have seen, which they entitled, "Driven." Their success inspired me to continue it a second semester, but after two semesters "Driven" was the only secondary presentation that stood out and multiple student comments indicated they would have preferred a review session led by me rather than by the students, which seemed quite reasonable.
}

\footnotetext{
${ }^{17}$ See Marie Hooper, "From Content to Process: A World Civilization Teaching Experiment," Teaching History 34, 1 (2009), 17-28. In this reflective essay she describes a student-driven history survey course which ultimately saw high engagement but only slight gains in student learning including having a majority of the students reporting they worked harder in that class for less knowledge. To be fair, she planned to revise it and continue it although to add in more lecture in the future. Another interesting read is Stanley J. Solomon, "Can We Discuss This? The Passing of the Lecture," The Midwest Quarterly 46, 1 (2004), 83-94.
} 
When times change, technology opens up new doors and students become more and more "fluent" in the new technology. Even a cursory look at the educational landscape underscores how quickly those teachers who do not adapt and integrate new elements fall behind. By simply engaging students to do sound historical work in the digital realm, we can continue to demonstrate the relevance and importance of history in a way that is engaging, interesting, rigorous, and integrative. I have found that the inclusion of student-created mini-documentaries provides a great source of learning for my history survey courses without the hassle of frequently off-task discussions and cooperation rather than learning.

\section{Appendix A}

\section{Mini-Documentary Assignment Instructions (U.S. History II)}

Overview: It is important to recognize that there are many trends and themes that have carried on throughout American history. Because they are often revisited, these trends help us recognize that the study of history is relevant today in that knowing the influences of these themes historically helps us get a stronger perspective from which to analyze today's events in their full context.

Checklist of Requirements: You will post your individual project on Blackboard in the "Project Forum" and bring two electronic copies of it with you to class on presentation day-burn one to a $\mathrm{CD}$ and have another on a flash drive. Late assignments will be unaccepted-if you are having a problem with the assignment contact me WELL BEFORE IT IS DUE. It is advised that you test your finished product on a few computers because, if a technical problem exists, it will reduce your grade. Be sure your project functions properly.

Create a mini-documentary-type movie on your topic

- Five to ten minutes in length

- Inclusion of a substantial amount of pictures, images, graphs, charts, etc. to provide visual overlay for your presentation (video is ok, too, but not long clips!)

- Inclusion of text on the screen to highlight key information

- Your narration providing the information for the video

- If you are unable to make an electronic copy of your narration, contact me once you have the final script of your narration-I will allow you to use my recorder and then email the MP3 to you, save it to your flash drive, or post it on Blackboard so that you can integrate 
it into your presentation; IF YOU NEED MY HELP WITH THIS, ASK IN ADVANCE OF WHEN YOUR PROJECT IS DUE!!

- Saved as an MP4 or AVl as they are highly compatible; if you need help finalizing products or converting them to these formats, contact me ahead of time.

Ensure that you provide as many details as you can in the time available to give a complete story to your topic.

$\square$ Focus on issues that are most significant (if you are unsure or have questions, ask me!)

$\square$ Include analysis of the significance of your item on U.S. history; what impact did it have? Direct and Indirect acceptable so long as they are clearly explained.

$\square \quad$ Submit an Annotated Bibliography of sources used to acquire information for the production of your movie on presentation day-you must have a minimum of eight sources, at least three of which are primary sources.

Go to www.Lynda.com and watch the video they have for the program you want to use - once you have done that, you may contact me with questions. I recommend iMovie or Windows Movie Maker; both are very user friendly and produce good quality "videos." If you are still uncomfortable, stop in during my office hours and I will give you a crash course in using a relevant program.

\section{Appendix B}

\section{Sample Thematic Topics: U.S. History II (1865-present)}

\section{Group Project Themes}

This list of the broad themes will encompass the final exam essay questions and will be traced throughout this course. The individual and group presentations will serve as an incredibly useful resource in preparing for the final exam, making it imperative that you do them to the highest standard. Note: a few topics are more contemporary, but are included to demonstrate the relevance of history-we are living it! Note II: the U.S. Constitution is ratified well before our course's coverage begins, but as the foundational piece to America's constitutional republic it seems essential to include it to serve as a base from which to see its development.

\section{Theme \#1: United States Reform}

- The Progressive Movement - The Conservative Resurgence - Populist Movement - Civil Rights Movement - Women's Rights Movement 
Theme \#2: Constitutional Development \& Politics

- The U.S. Constitution

- Supreme Court in the Twentieth Century

- Politics of Immigration - Republican Party in the Twentieth Century

- Third Parties in U.S. History - Democrat Party in the Twentieth Century

Theme \#3: War and Diplomacy

- Spanish-American War

- World War I

- World War II

- Korean War

- Vietnam War

- Desert Storm

Theme \#4: Societal Upheaval

- Pullman/Homestead Strikes - Al Capone

- Occupy Wall Street

- The Year of 1968

- Tea Party movement

Theme \#5: United States in a Global Context

- Age of Imperialism - The Great Depression

- Capitalism v. Communism - International Terrorism

Theme \#6: Economic Transformation

- The Federal Reserve - New Deal Economic Changes

- Second Industrial Revolution - Laissez Faire Economic Policy

Theme \#7: Influential Presidents

- Theodore Roosevelt

- Dwight D. Eisenhower

- Franklin D. Roosevelt

- Ronald W. Reagan

\section{Appendix C}

Thematic Group Presentation Instructions (U.S. History II)

\section{Group Presentation Requirements}

You will produce, as a group, an approximately fifteen-slide PowerPoint presentation following the format outlined below and incorporating specific information from your individual projects and making connections to contemporary America and/or the near future. Please note that while it will not be a major problem if your PPT is not exactly fifteen slides, it had better not deviate much from it. Be concise but provide the needed detail for our review. 
This group project will be completed as a review activity on the final day our class meets. Upon completion, the group will post the review PPT to Blackboard and between that day and the final should download and review each thematic reviews. The final exam will consist of three randomly selected essay questions from the seven possible themes in addition to the multiple choice section. These review presentations will be indispensable in preparing you to succeed on the final.

Once your group is all together, send up one person to Dr. Krahenbuhl to pick up the specific essay question that relates to your theme.

Requirements

\begin{tabular}{|c|c|c|}
\hline Slide \# & Topic & What to Include \\
\hline $\mathbf{1}$ & TITLE & $\begin{array}{l}\text { (1) The name of your theme } \\
\text { (2) Visual images that relate to your theme }\end{array}$ \\
\hline $\mathbf{2}$ & OVERVIEW & $\begin{array}{l}\text { (1) Create a clear \& concise definition of your theme } \\
\text { (2) Include one image that seems to best encompass that } \\
\text { theme }\end{array}$ \\
\hline $\mathbf{3 - 1 1}$ & $\begin{array}{c}\text { TOPICS IN } \\
\text { BRIEF DETAIL }\end{array}$ & $\begin{array}{l}\text { (1) 2 slides will be used to briefly recount each individual } \\
\text { topic listed from the course syllabus } \\
\text { (2) For each topic follow the steps outlined in a-c } \\
\text { [a] Name of topic + an encyclopedia entry overview of } \\
\text { what it was } \\
\text { [b] Visual images related to the topic + a one sentence } \\
\text { explanation of its historical significance } \\
\text { [c] A clear connection of how this topic illustrates the } \\
\text { theme and impacted US history }\end{array}$ \\
\hline $\mathbf{1 2}$ & $\begin{array}{c}\text { COMPARE \& } \\
\text { CONTRAST }\end{array}$ & $\begin{array}{l}\text { Develop a compare \& contrast of the topics previously } \\
\text { reviewed and their relationship to the theme (Venn Diagram, } \\
\text { chart, etc.) }\end{array}$ \\
\hline $\mathbf{1 3}$ & $\begin{array}{c}\text { IMPACTS OF } \\
\text { THESE EVENTS }\end{array}$ & $\begin{array}{l}\text { Construct a chart with 3 columns that identifies (1) social } \\
\text { impacts of this theme on US History, (2) political inpacts of } \\
\text { this theme on US History, \& (3) economic impacts of this } \\
\text { theme on US History }\end{array}$ \\
\hline CONCLUSION & $\begin{array}{l}\text { Develop a timeline of significant events that relate to your } \\
\text { theme in US History from 1865 to the present - include at a } \\
\text { minimum, specific events related to the topics listed in the } \\
\text { course syllabus and also several others (10 dates needed) }\end{array}$ \\
$\begin{array}{l}\text { Create a paragraph overview of the THEME and its } \\
\text { impacts/relationship to the story of American History from } \\
\text { 1865 to the present }\end{array}$ \\
\hline
\end{tabular}




\section{Appendix D}

\section{Sample Themed Final Exam Essay Questions (U.S. History II: 1865-Present)}

1) Compare and contrast three significant reform movements in American history in terms of their impacts socially, politically, and economically. Confine your response to the years 1865 to 2000 .

2) Compare and contrast three significant wars in American history, distinguishing between social, political, and economic impacts on the United States. Confine your response to the years 1865 to 2000.

3) Compare and contrast three significant American presidents, focusing on their domestic and foreign agendas and their impacts on American society. Confine your response to the years 1865 to 2000 .

4) Analyze how the United States is but one nation in a global context. Do so by discussing three distinct events that impacted both America and the world. Evaluate the impacts that resulted from these international events and place America's role directly into the global context. 